\title{
Modelling of chlorophyll- $a$ and Microcystis aeruginosa decay under the effect of different oxidants in culture media
}

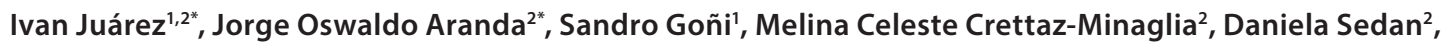 \\ Darío Andrinolo², Tomás Lombardo ${ }^{3}$, Guillermo Blanco ${ }^{3}$ and Leda Giannuzzi ${ }^{1,2}$ \\ 'Centro de Investigación y Desarrollo en Criotecnología de Alimentos, Consejo Nacional de Investigaciones Científicas y Tecnológicas, \\ Universidad Nacional de La Plata, Argentina \\ ${ }^{2}$ Área de Toxicología General, Facultad de Ciencias Exactas, Universidad Nacional de La Plata, La Plata, Argentina \\ 3Instituto de Estudios de la Inmunidad Humoral (IDEHU), Cátedra de Inmunología de la Facultad de Farmacia y Bioquímica, Universidad \\ de Buenos Aires, Argentina \\ *These authors contributed equally to this work.
}

Blooms of the cyanobacterium Microcystis aeruginosa are common in many eutrophic freshwater bodies and pose a serious threat to water quality, potentially giving rise to high turbidity, food web alterations, increased production of toxic microcystin (MC-LR) and odorous compounds. The comparative effectiveness of oxidant treatment of $M$. aeruginos a cells in culture media was evaluated by applying a mathematical model of chlorophyll- $a(\mathrm{Chl}-a)$, cells and MC removal. The oxidants were chlorine $\left(1-5 \mathrm{mg} \cdot \mathrm{L}^{-1}\right)$, hydrogen peroxide (HP: $50-150 \mathrm{mg} \cdot \mathrm{L}^{-1}$ ), percitric acid (PCA: $10-50 \mathrm{mg} \cdot \mathrm{L}^{-1}$ ), and peracetic acid (PAA: $1.5-7.5 \mathrm{mg} \cdot \mathrm{L}^{-1}$ ). The Weibull distribution model was applied to assess the degree of inactivation of $M$. aeruginosa viability under different oxidant treatments. First-order kinetics was successfully applied to the experimental data for Chl-a decay. Using the Weibull model, it was possible to predict the required exposure time $\left(T_{r}\right)$ for oxidants to achieve a $99.9 \%$ reduction in viable $M$. aeruginosa cells with respect to the initial value. $5 \mathrm{mg} \cdot \mathrm{L}^{-1} \mathrm{chlorine}$ produced a $81 \%$ degradation of [D-Leu'] MC-LR after $72 \mathrm{~h}$, with an exposure time $\left(\mathrm{T}_{\mathrm{r}}\right)$ of $141 \mathrm{~h}$. Among the peroxide treatments (HP, PCA and PAA), PCA (10-50 $\left.\mathrm{mg} \cdot \mathrm{L}^{-1}\right)$ produced the highest level of [D-Leu'] MC-LR degradation (39-79\%), with low exposure times $\left(T_{r}=119-125 \mathrm{~h}\right)$. Chl- $a$ concentration and $M$. aeruginosa counts for each oxidant treatment were highly correlated and successfully linked by a cubic polynomial. This is the first modelling report of M. aeruginosa decay by oxidant treatments.

\section{INTRODUCTION}

The appearance of cyanobacterial blooms in freshwater bodies is a growing phenomenon throughout the world (Paerl and Huisman, 2008, 2009; Jöhnk et al., 2008; Kosten et al., 2012). Cyanobacterial blooms develop mainly during summer in eutrophic freshwater ecosystems with stagnant water (Harke et al., 2016). This is a fallout of the impact of human activities (such as nutrient downloads) on freshwater bodies as well as the effect of climate change on the ecosystem. Cyanobacteria can produce cyanotoxins and thus impact strongly on important ecosystem services such as recreation and fishing, aquaculture, irrigation and drinking water treatment. The control of cyanobacterial blooms is an important challenge that requires an early solution, considering the fact that the cyanobacterial phenomenon is likely to increase in climate change scenarios (Paerl and Huisman, 2008; Jöhnk et al., 2008; Matthijs et al., 2016). Additionally, a significant increase in the costs of treating water intended for human consumption should be considered (Aguilera and Echenique, 2017).

Paerl and Otten (2013) reported that about $50-75 \%$ of cyanobacterial blooms are toxic and have caused a serious threat to human and animal health because of the potent hepatotoxins, neurotoxins and dermatotoxins that they release into water bodies (WHO, 1999). Microcystin-LR (MC-LR) generated by $M$. aeruginosa is the most abundant and common hepatotoxin found in cyanobacterial blooms in fresh and brackish waters (Paerl and Otten, 2013; Westrick et al., 2010; Zamyadi et al., 2013). Chronic exposure to sub-lethal concentrations of microcystins is the most common form of intoxication in wild and domestic animals and humans. A correlation has been reported between high levels of primary liver cancer in the regions of Southeast Asia and China and the consumption of surface water where blooms of toxic cyanobacteria are very frequent (Ueno et al., 1996; Zhao et al., 2009).

MC-LR has been identified as one of the highest priority toxins to be studied based on four criteria (USEPA, 2015):

- Its effect on human health

- Its frequency of occurrence in bodies of water

- Its susceptibility to the treatments used in water treatment plants

- The stability of the toxin

The preferred method of preventing these blooms is to reduce the nutrient load of surface waters, although this is not always feasible. Various chemical methods have also been widely adopted, such as addition of algicide (copper sulfate), oxidants (chlorine, potassium permanganate) and flocculants $\left(\mathrm{FeCl}_{3}, \mathrm{AlCl}_{3}\right.$, polyaluminum chloride) etc., all of which have proven to be efficient

\section{CORRESPONDENCE}

Leda Giannuzzi

EMAIL

leda@biol.unlp.edu.ar

\section{DATES}

Received: 12 July 2019

Accepted: 29 June 2020

\section{KEYWORDS}

Microcystis aeruginosa

microcystin

mathematical model

oxidants

chlorophyll-a decay

Weibull model

\section{COPYRIGHT}

(c) The Author(s)

Published under a Creative

Commons Attribution 4.0

International Licence

(CC BY 4.0) 
in removing cyanobacteria cells. However, the persistence of some chemical compounds can potentially induce secondary pollution, harming aquatic organisms and even humans. Some oxidants used as part of drinking water treatment or as pre-treatment of surface water destined for the production of drinking water, can cause the release of toxins, and the subsequent rapid oxidation of the toxins must therefore be assured (Zamyadi et al., 2013; Stanford et al., 2016; Rositano et al., 2001).

Hydrogen peroxide (HP), percitric acid (PCA) and peracetic acid (PAA) are alternative disinfectants, owing mainly to the fact that the formation of disinfection by-products (DBPs) and the overall toxicity during their use is much lower than with chlorine or ozone (Booth and Lester, 1995, Monarca et al., 2002; Crebelli et al., 2005). The principal PAA and PCA end-products are acetic acid, citric acid, HP, oxygen and water. PAA is a sustainable disinfectant in aquaculture and it completely degrades into harmless residues within several hours after application (Lefevre et al., 1992). However, its usage in drinking water treatment is still an evolving topic.

The main aim of this study was to evaluate the effectiveness of HP, PAA and PCA treatment on M. aeruginosa cells in culture media compared to chlorine, and to mathematically model the kinetic of Chl- $a$ and cell removal.

\section{MATERIAL AND METHODS}

\section{Strain preservation}

A toxigenic non-axenic strain of $M$. aeruginosa (CAAT2005-3) previously reported as a [D-Leu $\left.{ }^{1}\right]$ MC-LR producer was used (Rosso et al., 2014). This strain was isolated from the environment and remained unicellular in culture under laboratory conditions. The strain is maintained by periodic passage (every 15 days) through modified BG11 culture medium at $25^{\circ} \mathrm{C}( \pm 1)$ and light intensity $30 \mu \mathrm{mol} \cdot \mathrm{photon} \cdot \mathrm{s}^{-1} \cdot \mathrm{m}^{-2}$ with constant aeration with humidified sterile air (Barroin and Feuillade, 1986).

\section{Experimental design}

For assays, the $M$. aeruginosa strain was grown in triplicate in modified BG11 medium (nitrogen phosphorus ratio 10) in $1000 \mathrm{~mL}$ Erlenmeyer flasks under controlled temperature conditions $\left(25^{\circ} \mathrm{C} \pm 1\right)$, constant aeration with humidified sterile air, a fluorescent light intensity of $30 \mu \mathrm{mol}$ photons $\cdot \mathrm{s}^{-1} \cdot \mathrm{m}^{-2}$ and a lightdark cycle of 10:14 h. Prior to the experiments, the cultures were acclimated for 7 days at $10^{4}-10^{5}$ cell $\cdot \mathrm{mL}^{-1}$ inoculum, periodically adding the culture medium.

Non-axenic $M$. aeruginosa cultures $\left(10^{5}\right.$ and $10^{6}$ cells $\cdot \mathrm{mL}^{-1}$ and Chl- $a 2$ 000-2 $500 \mu \mathrm{g} \cdot \mathrm{L}^{-1}$ ) were used to simulate a heavy bloom concentration and treated with different concentrations of $\mathrm{HP}$, PAA, PCA and chlorine. All treatments were carried out in batch mode, using Erlenmeyer flasks containing cyanobacterial culture. Stabilized HP (Fluka, 30\%) was added to achieve 50, 100 and $150 \mathrm{mg} \cdot \mathrm{L}^{-1}$. The selected HP doses were within the ranges reported in the literature (Fan et al., 2013; Wang et al., 2012; Huo et al., 2015). PAA and PCA treatment tests were carried out employing the commercial product SABINUR, an equilibrium mixture containing peracetic acid or percitric acid (15\% mass/volume, $\mathrm{m} / \mathrm{v})$, hydrogen peroxide $(30 \% \mathrm{~m} / \mathrm{v})$ and stabilizing vehicle. PAA and PCA doses were $1.5,3.0$, and $7.5 \mathrm{mg} \cdot \mathrm{L}^{-1}$ and 10,30 and $50 \mathrm{mg} \cdot \mathrm{L}^{-1}$, respectively. A control experiment without oxidants was performed.

Chlorine stock solution concentrations ranged from 4 000-5 000 $\mathrm{mg} \cdot \mathrm{L}^{-1}$ as free chlorine. For chlorine experiments, cyanobacterial samples were dosed with chlorine to achieve the desired chlorine concentrations $\left(1,3\right.$ and $\left.5 \mathrm{mg} \cdot \mathrm{L}^{-1}\right)$.

To inactivate the residual of PAA, PCA and chlorine after the specified contact time, sodium thiosulfate (1\%) was added in the proportion $0.1 \mathrm{~mL}$ for each $100 \mathrm{~mL}$ of sample. Catalase was applied to inactive HP residual. The control and treated cultures were placed in a controlled environment growth chamber (Ingelab $\mathrm{I}-292 \mathrm{PF}$ ) at $25^{\circ} \mathrm{C}$; the average irradiance in the incubator was $30 \mu \mathrm{mols}^{-1}$.photon $\cdot \mathrm{m}^{-2}$ with a light-dark cycle of $10: 14 \mathrm{~h}$.

At different times during the experiment $(0,24,48$ and $72 \mathrm{~h})$, samples of the cultures were taken and $\mathrm{pH}$, concentration residuals of chlorine, HP, PAA and PCA, Chl- $a$ and M. aeruginosa viability determinations were performed. All experiments were conducted with three independent replicates.

\section{pH determination}

$\mathrm{pH}$ determination was performed with a $\mathrm{pH}$ metro electrode Sper Scientific Water Quality Meter Model 850081.

\section{Residual concentration of chlorine, HP, PAA and PCA}

Chlorine stock concentrations and free chlorine residuals were determined using the DPD-FAS titration method described in Standard Methods (APHA, 2005). Peroxide residuals were analysed by Quantofix test sticks (Machereye-Merck, Darmstadt, Germany). It was possible to refine the measurements by taking photographs of each test stick and then comparing these with our own calibration series according to the procedure described by Matthijs et al. (2012). PAA and PCA concentrations were determined by iodometric titration according to a two-step procedure developed for PAA determination (Pinkenell, 1994). First, hydrogen peroxide was consumed by the addition of catalase from bovine liver (2 000-5 000 unit. $\mathrm{mg}^{-1}$, Sigma) and then PAA or PCA was titrated by thiosulfate addition (Falsanisi et al., 2006).

\section{Determination of $\mathrm{Chl}-\mathrm{a}$}

Chl- $a$ was determined by the $100 \%$ methanol extraction method according to the technique of Marker et al. (1980). The spectrophotometric reading at 665 and $750 \mathrm{~nm}$ before and after acidification with $1 \mathrm{~N} \mathrm{HCl}$ were performed. Chl- $a$ concentrations were expressed as $\mu \mathrm{g} \cdot \mathrm{L}^{-1}$.

\section{Modelling Chl-a decay}

Modelling Chl- $a$ decay by first-order kinetics:

$$
\frac{\partial C}{\partial t}=k_{0} \times C
$$

Integrating Eq. 1, the Eq. 2 was obtained:

$$
\ln \left(\frac{C}{C_{0}}\right)=k_{0} \times t
$$

where $k_{0}$ is the first-order decay constant $\left(\mathrm{h}^{-1}\right), C$ is the Chl- $a$ concentration at time $t, C_{0}$ is the initial Chl- $a$ concentration $\left(\mu \mathrm{g} \cdot \mathrm{L}^{-1}\right)$, and $t$ is the time (h); $k_{0}$ (the slope of the model) is obtained through the linear regression under each condition.

The time required for the concentration of Chl- $a$ to decay to half the initial values $\left(t_{m}\right)$ was calculated using Eq. 3 .

$$
t_{m}=\frac{\ln (0.5)}{k_{0}}
$$

A linear relationship between $k_{0}$ values and the oxidant concentration was proposed:

$$
k_{0}=a+b \times C
$$

where $a$ is the interception of $y$-axes, $b$ is the slope and $C$ is the concentration of the different oxidants used.

For each oxidant used in the experiments, the $\left(\mathrm{EC}_{50}\right)_{\mathrm{Chl}-a}$ values (defined as the concentration of oxidants $\left(\mathrm{mg} \cdot \mathrm{L}^{-1}\right)$ at which $50 \%$ of Chl- $a$ were degraded at $72 \mathrm{~h}$ ) were obtained by the linear interpolation method. 


\section{Evaluation of $M$. aeruginosa cell viability by flow cytometry}

Cell viability was assessed by flow cytometry using a Partec PAS III instrument equipped with a $488 \mathrm{~nm}$ argon laser as excitation source, and a volumetric injection system for the absolute count of analysed cells. Cells were labelled with SYTOX green, and non-viable cyanobacteria were identified by green fluorescence emission at $520 \mathrm{~nm}$ (FL1).

A $3 \mathrm{~mL}$ aliquot was centrifuged at $5000 \mathrm{~g}$ for $10 \mathrm{~min}$, and then the cells were incubated with Sytox Green (Thermo Fisher Scientific) at a final concentration of $1 \mathrm{nM}$ for $30 \mathrm{~min}$ in the dark (Tashyreva et al., 2013). The dye binds to nucleic acids and cannot penetrate the membrane of living cells. However, when the membranes are compromised, it easily penetrates the cell producing a bright green fluorescence indicative of dead cells.

Analysis of flow cytometry data was conducted with Flomax 2.7 software. Using this approach, the absolute number of viable $M$. aeruginosa and the fraction of dead cells at each point in time after treatment were evaluated. Survival curves were then generated from the experimental data by plotting $\log \left(N / N_{0}\right)$ (where $N$ is the number of viable cells of $M$. aeruginosa at a given time, and $N_{0}$ is the initial number of viable cells and was expressed as cells $\cdot \mathrm{mL}^{-1}$ versus treatment time.

\section{Modelling M. aeruginosa survival curves}

The Weibull distribution is a flexible and convenient model for describing microbial survival curves when the kinetic is not linear. It is a continuous probability distribution which has been extensively used to study survival curves and inactivation kinetics of different microorganisms (Chun et al., 2009; González et al., 2009; Mafart et al., 2002; Peleg and Cole, 1998).

M. aeruginosa survival curves were fitted using the Weibull model (Eq. 5):

$$
\log \left(\frac{N}{N_{0}}\right)=-B \times t^{n}
$$

where $N$ and $N_{0}$ are the viable cells number (cells. $\mathrm{mL}^{-1}$ ) present at time $t$ and zero, respectively; $t$ is time (h); $B$ is the scale parameter, which could be considered as a kinetic rate parameter; and $n$ is the shape parameter, which describes the shape of the curve. The experimental data were fitted to the proposed model using a nonlinear regression technique.

If $n=1$, a first-order kinetics is obtained; $n<1$ signifies a strong right skew of the distribution and the semi-logarithmic survival curve has a noticeable upward concavity. When $n>1$, i.e., the semilogarithmic survival curve has a marked downward concavity, the underlying distribution can have a left skew, depending on the value of $B$ (Peleg and Cole, 1998).

Predictions of the time for a given decrease in the microbial population $\left(T_{r}\right)$ can be derived from Eq. 5 by Eq. 6 :

$$
T_{r}=\left(\frac{\log \left(\frac{N}{N_{0}}\right)}{-B}\right)^{1 / n}
$$

\section{Total mesophilic heterotrophic bacteria counts}

Considering that $M$. aeruginosa is a non-axenic culture, heterotrophic bacteria in the M. aeruginosa culture were counted at the beginning and the end of the experiment. For that, $1 \mathrm{~mL}$ of serial dilution of culture was placed on plate count agar (PCA) using the plate pour procedure with incubation at $37^{\circ} \mathrm{C}$ for $24-48 \mathrm{~h}$. This is the most used procedure for enumeration of total aerobic mesophilic heterotrophic microorganisms. Determinations were made in triplicate. An Ionomex colony counter was used to quantify the bacteria colony and the results were expressed as colony forming units for $\mathrm{g}\left(\mathrm{CFU} \cdot \mathrm{mL}^{-1}\right)$.

\section{[D-Leu'] MC-LR quantification}

Aliquots of culture were submitted to ultrasonication for $30 \mathrm{~min}$ (Omni Ruptor 400) and then centrifuged for $15 \mathrm{~min}$ at $5000 \mathrm{r} \cdot \mathrm{min}^{-1}$ to eliminate cell debris. The supernatant was passed through previously conditioned Sep-Pak C18 cartridges

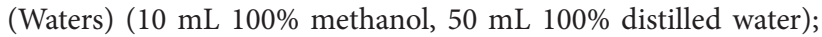
the MCs were then eluted with $80 \%$ methanol (Barco et al., 2005). Quantitative chromatographic analysis of MCs was performed by HPLC/MS Shimadzu LCMS-2020 to determine the principal component of [D-Leu ${ }^{1}$ MC-LR toxins $(\mathrm{m} / \mathrm{z}$ 520) using C18 column (Hyperprep HS, 5- $\mu \mathrm{m}$ pore, $250 \mathrm{~mm} 10 \mathrm{~mm}$ ) according to Giannuzzi et al. (2016). The column was equilibrated with a mixture that was composed of $65 \%$ A solution (water with $0.05 \%(\mathrm{v} / \mathrm{v})$ trifluoroacetic acid) and 35\% B solution (acetonitrile with $0.05 \%(\mathrm{v} / \mathrm{v})$ formic acid). The mobile phase consisted of a discontinuous gradient of $\mathrm{A}$ and $\mathrm{B}$ solutions. Initial conditions were $100 \% \mathrm{~B}$, followed by a linear gradient to $50 \% \mathrm{~B}$ in $1 \mathrm{~min}$, isocratic elution min with $50 \%$ B for $5 \mathrm{~min}$, then a linear gradient to $90 \%$ B for 15 min followed by isocratic elution with $90 \%$ B for $20 \mathrm{~min}$ and returning to initial conditions for $21 \mathrm{~min}$ followed by 9 min column equilibration with $0 \% \mathrm{~B}$ (total run time: $30 \mathrm{~min}$ ). The flow rate was $1.0 \mathrm{~mL} \cdot \mathrm{min}^{-1}$. Standard of MC-LR was purchased from Sigma (St Louis, MO, USA). [D-Leu $]^{1}$ MC-LR was expressed as $\mu \mathrm{g} \cdot \mathrm{L}^{-1}$.

\section{Transmission electron microscopy (TEM)}

The cells of the treated cultures and the control were centrifuged at $1500 \mathrm{r} \cdot \mathrm{min}^{-1}$ for $10 \mathrm{~min}$ and fixed with $2 \%$ glutaraldehyde in phosphate buffer ( $\mathrm{pH} 7.2-7.4)$ for $2 \mathrm{~h}$ at $4^{\circ} \mathrm{C}$. A secondary fixation was performed with $1 \%$ osmium tetroxide $\left(\mathrm{OsO}_{4}\right)$ for $1 \mathrm{~h}$ at $4^{\circ} \mathrm{C}$. After graded alcohol dehydration, samples were embedded in epoxy resin. Sections were cut, stained with uranyl acetate and lead citrate and examined with a JEM 1200 EX II transmission electron microscope (JEOL Ltd., Tokyo, Japan) and photographed with an Erlangshen ES1000W camera, Model 785 (Gatan Inc., Pleasanton, California, USA) of the Central Service of Electronic Microscopy of the Faculty of Veterinary Sciences, UNLP.

\section{Statistical analyses}

The results of the experiments were presented as the mean ( \pm standard deviation) of 3 independent determinations. Analysis of variance (ANOVA) and comparison tests according to the Fisher significant differences table (least significant difference) were applied with significance levels of 0.05 . The statistical requirements for the ANOVA (normal distribution, homogeneity of variance and independence) were performed prior to executing ANOVA. The variables tested were $k_{0}$ values for Chl- $a$ assays and $n$ and $B$ parameters obtained by using the Weilbull model, and the factors were the different concentrations of each oxidant. The statistical software Systat (Systat version 5.0, Inc. Herndon, USA) was used. The different sets of data were obtained from the survival curves of $M$. aeruginosa after exposure to different oxidant concentrations. Non-linear regressions were carried out using Systat (Systat Inc., version 13.1, Washington, USA). The goodness-of-fit was evaluated by 2 parameters: coefficient of determination $\left(R^{2}\right)$ and the root-mean-square error (RMSE) defined in Eq. 7.

$$
\text { RMSE: } \sqrt{\frac{\sum(\text { experimental-predicted })^{2}}{c-d}}
$$

where 'experimental' is the experimental data, 'predicted' is the value predicted by the model, $c$ is the number of experimental data, and $d$ is the number of parameters of the assessed model. Lower RMSE values indicate a better fit of the model to describe the data (Snedecor and Cochran, 1969). 


\section{RESULTS}

\section{pH and residual oxidant concentration}

The initial $\mathrm{pH}$ value of the system ranged between 8.0 and 9.0 and remained unchanged throughout the experiment. All concentrations of the oxidants added (HP, PAA and PCA) decreased to levels below the detection limit $\left(0.1 \mathrm{mg} \cdot \mathrm{L}^{-1}\right)$ after $72 \mathrm{~h}$. This is in accordance with previous findings that the degradation of HP occurs in between 24 and 48 h (Bauzá et al., 2014).

No chlorine residual was detected in cultures at any doses used (1-5 mg. $\left.\mathrm{L}^{-1}\right)$ after $72 \mathrm{~h}$ due to chlorine consumption within the first minute of contact. The rapid initial chlorine reactivity was attributed to the high concentration of cells and organic material in the culture.

\section{Chlorophyll-a decay kinetics}

Chl- $a$ is known to be an important indicator of algal biomass (Izydorczyk et al., 2009). Before the oxidant application, the initial Chl- $a$ content in the culture was $2514 \mu \mathrm{g} \cdot \mathrm{L}^{-1}( \pm 545)$.
There was a clear increase, of 2 -fold, in the Chl- $a$ content over time in the control samples at $72 \mathrm{~h}$, reaching $4750 \mu \mathrm{g} \cdot \mathrm{L}^{-1}( \pm 550)$. When compared with the control, Chl- $a$ values of M. aeruginosa culture were lower for all samples with oxidizing agent treatment at $72 \mathrm{~h}$. Culture discoloration increased with an increase in the concentrations of the oxidizing agent. For example, Fig. 1 shows the culture appearance after $72 \mathrm{~h}$ of treatment with chlorine and PCA at all assayed concentrations.

Figure 2 shows the Chl- $a$ decay $\left(\right.$ as $\left.\ln \left(C / C_{0}\right)\right)$ vs. time under the different oxidant treatments. The value of $k_{0}$ for each treatment was obtained by linear regression (Table 1 ). Statistically significant differences $(p<0.05)$ were observed for $k_{0}$ values.

Table 1 also shows the growth rate (GR, positive values), which is the slope of the Chl- $a$ increase. Control and samples treated with $50 \mathrm{mg} \cdot \mathrm{L}^{-1}$ of $\mathrm{HP}$ and $1.5 \mathrm{mg} \cdot \mathrm{L}^{-1}$ of PAA show positive GR values. The negative slope of the linear regression is Chl- $a$ decay rate $\left(k_{0}\right)$. The $k_{0}$ values increase when increasing the doses of oxidizing agent and this indicates a faster Chl- $a$ decay. Chl- $a$ decay is more pronounced under $5 \mathrm{mg} \cdot \mathrm{L}^{-1}$ of chlorine treatment, with higher $k_{0}$ values (Table 1).

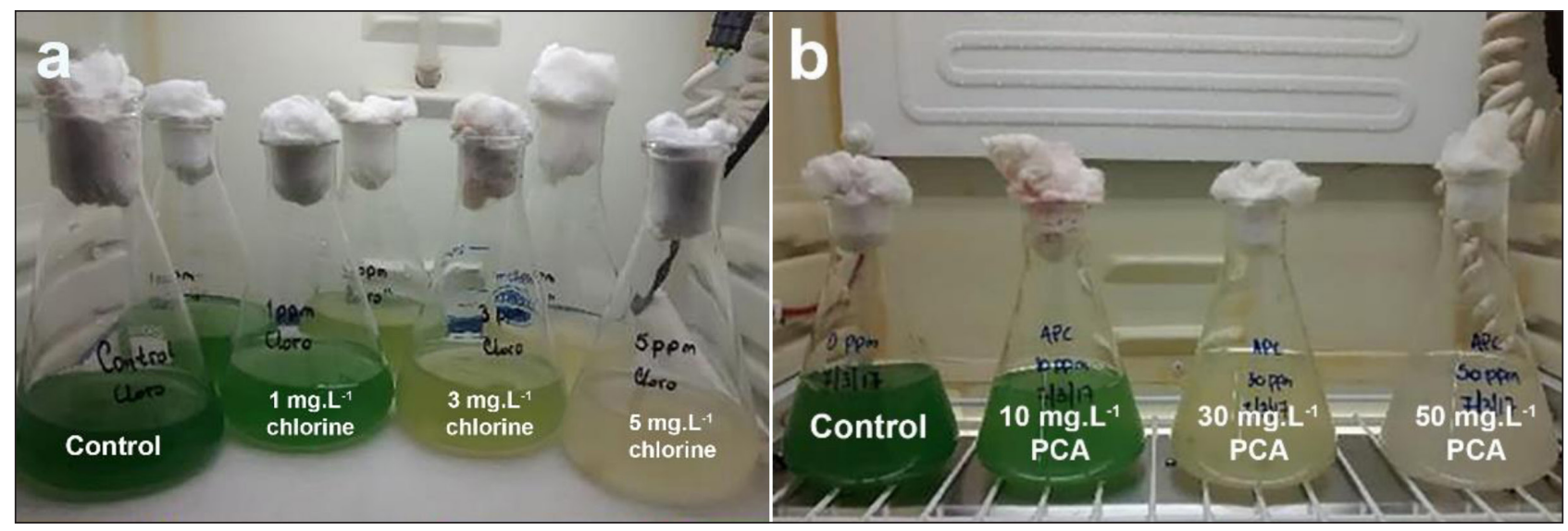

Figure 1. Effect of addition of oxidizing agent on the appearance of M. aeruginosa culture after $72 \mathrm{~h}$, (a) chlorine addition, (b) PCA addition

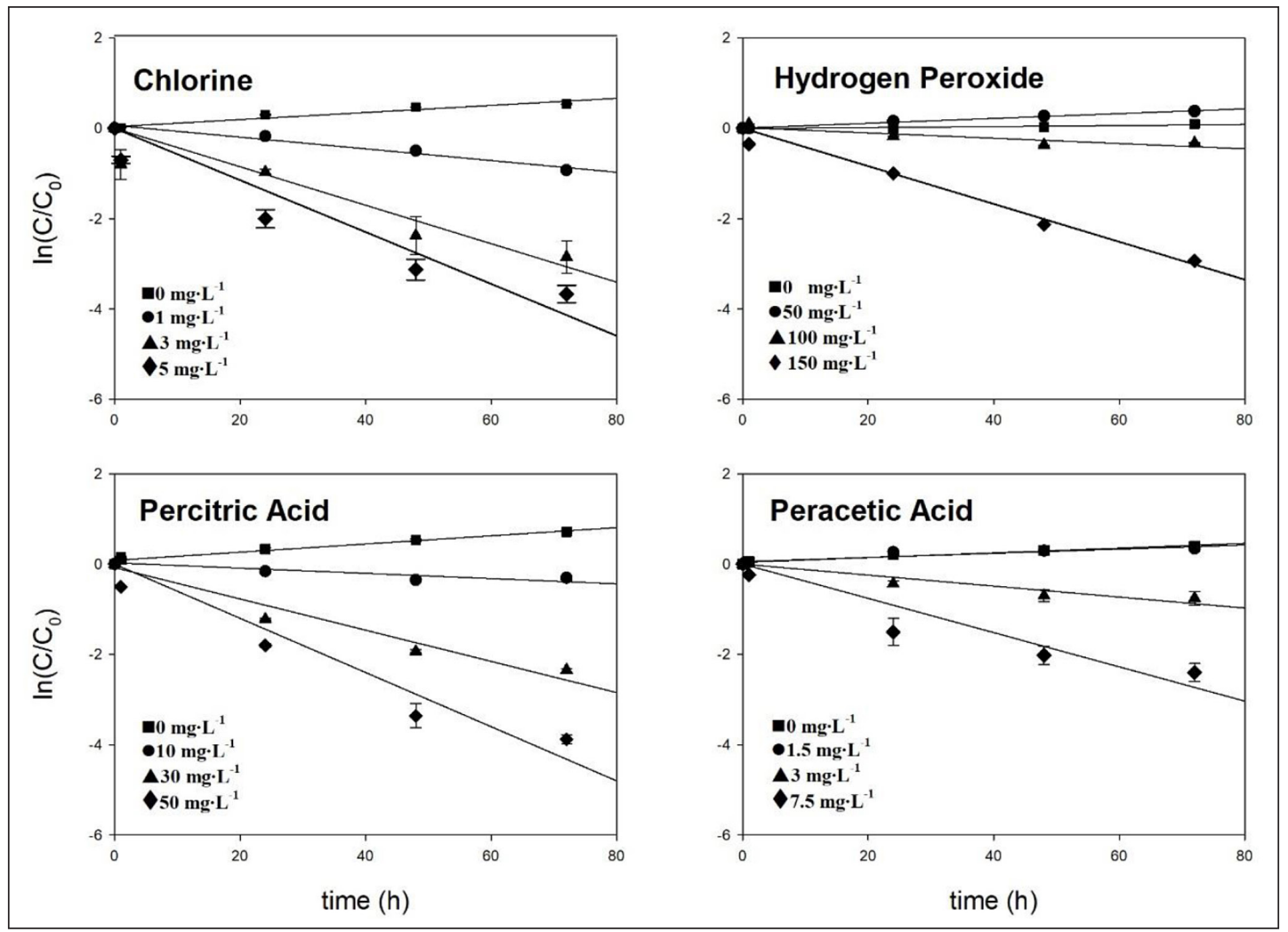

Figure 2. Kinetics of $\mathrm{Chl}-a$ decay in cultures of $M$. aeruginosa under different treatments. Bars indicate standard deviation of three independent determinations 
Table 1. Parameters obtained by fitting the pseudo-first-order Chl- $a$ kinetics with experimental data

\begin{tabular}{|c|c|c|c|c|c|}
\hline Treatment & $\begin{array}{l}\text { Doses } \\
\left(\mathrm{mg} \cdot \mathrm{L}^{-1}\right)\end{array}$ & $\begin{array}{c}k_{0} \text { or GR } \\
\left(h^{-1}\right)\end{array}$ & $R^{2}$ & $\begin{array}{l}t_{m} \\
\text { (h) }\end{array}$ & $\begin{array}{l}\left(\mathrm{EC}_{50}\right)_{\mathrm{chl}-\mathrm{a}} \\
\left(\mathrm{mg} \cdot \mathrm{L}^{-1}\right)\end{array}$ \\
\hline \multirow[t]{4}{*}{ Chlorine } & 0 & $8.56 \times 10^{-3}\left( \pm 4.7 \times 10^{-4}\right)^{a, b}$ & 0.97 & --- & 0.70 \\
\hline & 1 & $-1.19 \times 10^{-2}\left( \pm 2.5 \times 10^{-3}\right)^{b}$ & 0.75 & $58.24( \pm 8.9)$ & \\
\hline & 3 & $-4.26 \times 10^{-2}\left( \pm 5.1 \times 10^{-3}\right)^{c}$ & 0.84 & $16.27( \pm 4.8)$ & \\
\hline & 5 & $-6.67 \times 10^{-2}\left( \pm 8.6 \times 10^{-3}\right)^{c}$ & 0.85 & $10.39( \pm 2.6)$ & \\
\hline \multirow[t]{4}{*}{ HP } & 0 & $1.01 \times 10^{-2}\left( \pm 1.0 \times 10^{-3}\right)^{d}$ & 0.96 & ---- & 102.00 \\
\hline & 50 & $1.13 \times 10^{-3}\left( \pm 3.2 \times 10^{-4}\right)^{\mathrm{e}}$ & 0.99 & ---- & \\
\hline & 100 & $-5.90 \times 10^{-3}\left( \pm 1.6 \times 10^{-3}\right)^{\mathrm{e}}$ & 0.99 & ---- & \\
\hline & 150 & $-3.90 \times 10^{-2}\left( \pm 2.4 \times 10^{-3}\right)^{f}$ & 0.98 & $17.03( \pm 1.38)$ & \\
\hline \multirow[t]{4}{*}{ PCA } & 0 & $9.03 \times 10^{-3}\left( \pm 1.0 \times 10^{-3}\right)^{\mathrm{g}}$ & 0.82 & ---- & 17.56 \\
\hline & 10 & $-5.78 \times 10^{-3}\left( \pm 1.5 \times 10^{-3}\right)^{\mathrm{h}}$ & 0.87 & $123.77( \pm 20.9)$ & \\
\hline & 30 & $-3.46 \times 10^{-2}\left( \pm 4.4 \times 10^{-3}\right)^{h}$ & 0.97 & $19.09( \pm 1.21)$ & \\
\hline & 50 & $-5.37 \times 10^{-2}\left( \pm 1.3 \times 10^{-3}\right)^{\mathrm{i}}$ & 0.94 & $11.25( \pm 1.26)$ & \\
\hline \multirow[t]{4}{*}{ PAA } & 0 & $5.22 \times 10^{-3}\left( \pm 6.6 \times 10^{-4}\right)^{j}$ & 0.96 & ---- & 4.02 \\
\hline & 1,5 & $4.61 \times 10^{-3}\left( \pm 1.1 \times 10^{-4}\right)^{j}$ & 0.89 & ---- & \\
\hline & 3 & $-1.12 \times 10^{-2}\left( \pm 1.4 \times 10^{-3}\right)^{k}$ & 0.95 & $56.82( \pm 6.5)$ & \\
\hline & 7,5 & $-3.30 \times 10^{-2}\left( \pm 5.5 \times 10^{-3}\right)^{1}$ & 0.81 & $19.04( \pm 4.4)$ & \\
\hline
\end{tabular}

For each oxidizing agent, different letters indicate significant differences between values $(p<0.05)$. Results are presented as the mean ( \pm standard deviation) of three independent determinations.

The time to reach half of the initial Chl- $a$ concentration $\left(t_{m}\right)$ was calculated using Eq. 3. Positive growth rate values indicate absence of degradation of Chl- $a$, in which case $t_{m}$ was not calculated. As expected, for all oxidants, $t_{m}$ values decreased as oxidant concentration was augmented. The $t_{m}$ values ranged between 58.24 and $10.39 \mathrm{~h}$ for the treatment with chlorine. For experiments performed with HP, the $t_{m}$ value was $17.03 \mathrm{~h}$ at the highest concentration $\left(150 \mathrm{mg} \cdot \mathrm{L}^{-1}\right)$.

For PCA and PAA treatment, $t_{m}$ values ranged between 123.77 and $11.25 \mathrm{~h}$ and 56.82 and $19.04 \mathrm{~h}$, respectively (Table 1 ). $5.0 \mathrm{mg} \cdot \mathrm{L}^{-1}$ chlorine was found to be the concentration of oxidant able to degrade the concentration of Chl- $a$ to half its initial value in the shortest time $(10.39 \mathrm{~h})$. In order to take into account the effect of the addition of different concentrations of oxidants on $k_{0}$ values, a linear regression was applied showing a good correlation (Eq. 4).

The fitting parameters were $a=5.4 \times 10^{-3}\left( \pm 3.1 \times 10^{-3}\right), b=-1.5 \times 10^{-2}$ $\left( \pm 1.0 \times 10^{-3}\right)$ and $R^{2}=0.991$ for chlorine, $a=1.4 \times 10^{-2}\left( \pm 8.1 \times 10^{-3}\right)$, $b=-3.1 \times 10^{-4}\left( \pm 8.6 \times 10^{-5}\right)$ and $R^{2}=0.898$ for HP treatment, $a=7.2 \times 10^{-3}\left( \pm 2.7 \times 10^{-3}\right), b=-1.3 \times 10^{-3}\left( \pm 8.9 \times 10^{-5}\right)$ and $R^{2}=0.990$ for PCA and $a=4.1 \times 10^{-3}\left( \pm 8.9 \times 10^{-3}\right), b=-5.0 \times 10^{-3}$ $\left( \pm 2.2 \times 10^{-4}\right)$ and $R^{2}=0.997$ for PAA treatment (Fig. 3). Increase in Chl- $a$ decay rate is indicated by more negative values of $k_{0}$.

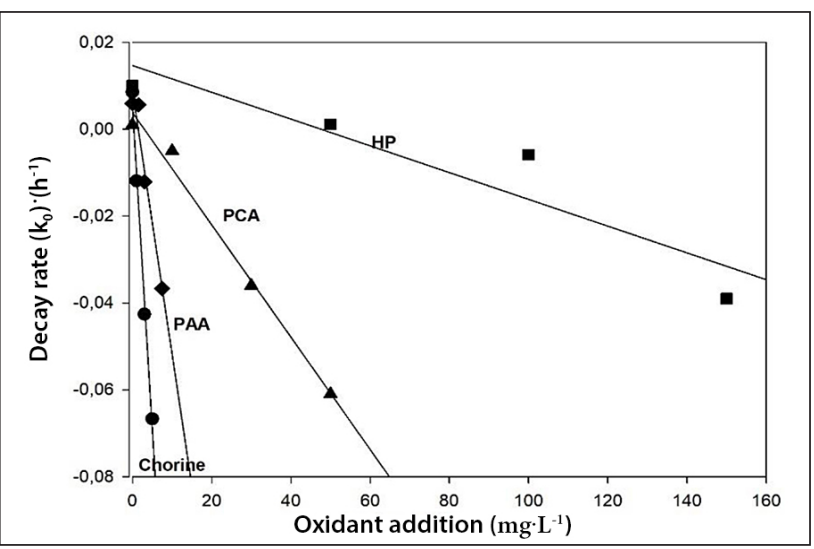

Figure 3. Effects of different oxidants on Chl- $a$ decay rate $\left(k_{0}\right)$
These parameters allow us to predict $k_{0}$ values at concentrations that are different from those applied in the present study. An alternative way of evaluating the effects of oxidants on the degradation of Chl- $a$ is through the effective concentration $\left(\mathrm{EC}_{50}\right)_{\mathrm{Chl}-a}$; the calculated values for each oxidant are presented in Table 1.

$\left(\mathrm{EC}_{50}\right)_{\mathrm{Chl}-a}$ shows that, of the four oxidants applied, chlorine was the most effective, since it required the lowest concentration values $\left(0.70 \mathrm{mg} \cdot \mathrm{L}^{-1}\right)$, followed by PAA $\left(4.02 \mathrm{mg} \cdot \mathrm{L}^{-1}\right)$. Higher concentrations of the remaining two oxidants were required (17.56 mg. $\mathrm{L}^{-1}$ for PCA and $102 \mathrm{mg} \cdot \mathrm{L}^{-1}$ for HP) (Table 1 ).

\section{Effect of oxidants on M. aeruginosa cell viability and heterotrophic bacteria counts}

The initial $M$. aeruginosa cell concentration for the experiments was around $9 \times 10^{5}-1 \times 10^{6}$ cells. $\mathrm{mL}^{-1}$. The effect of oxidation by chlorine, HP, PCA and PAA on $M$. aeruginosa viability was quantitatively assessed for individual cells by flow cytometry. Individual dead cells were identified by staining them with the fluorescent probe SYTOX green, a dye that only stains nucleic acids when the cell membrane is damaged and permeable. Therefore, alive cells showed low SYTOX green fluorescence, and untreated cells represented negative controls as shown in Fig. 4a. In contrast, dead cells had high green fluorescence with a right-shifted fluorescence intensity frequency distribution, as shown Fig. 4b. Those cells that lay within region RN2 shown in Fig. 4, according to their SYTOX green fluorescence intensity were considered dead. A positive sample (treated high oxidant dose) where all cells are dead is shown in Fig. 4b. In Fig. 4a, most cells are outside the RN2, indicating they are alive, while a minor fraction lies within the RN2 region. The correlation plots, FSC vs. SSC, shown in Figs 4a and $4 \mathrm{~b}$ illustrate that dead cells had lower FSC and lower SSC compared to live cells, while the correlation plots FL1 SYTOX vs. FL3-chl of the same panels show that dead cells had lower chlorophyll fluorescence than live cells. Therefore, live and dead cells were completely separated for each sample after using oxidizing agents. In addition, high SYTOX green fluorescence was also correlated to low SSC, FSC, and chlorophyll (FL3-chl). 

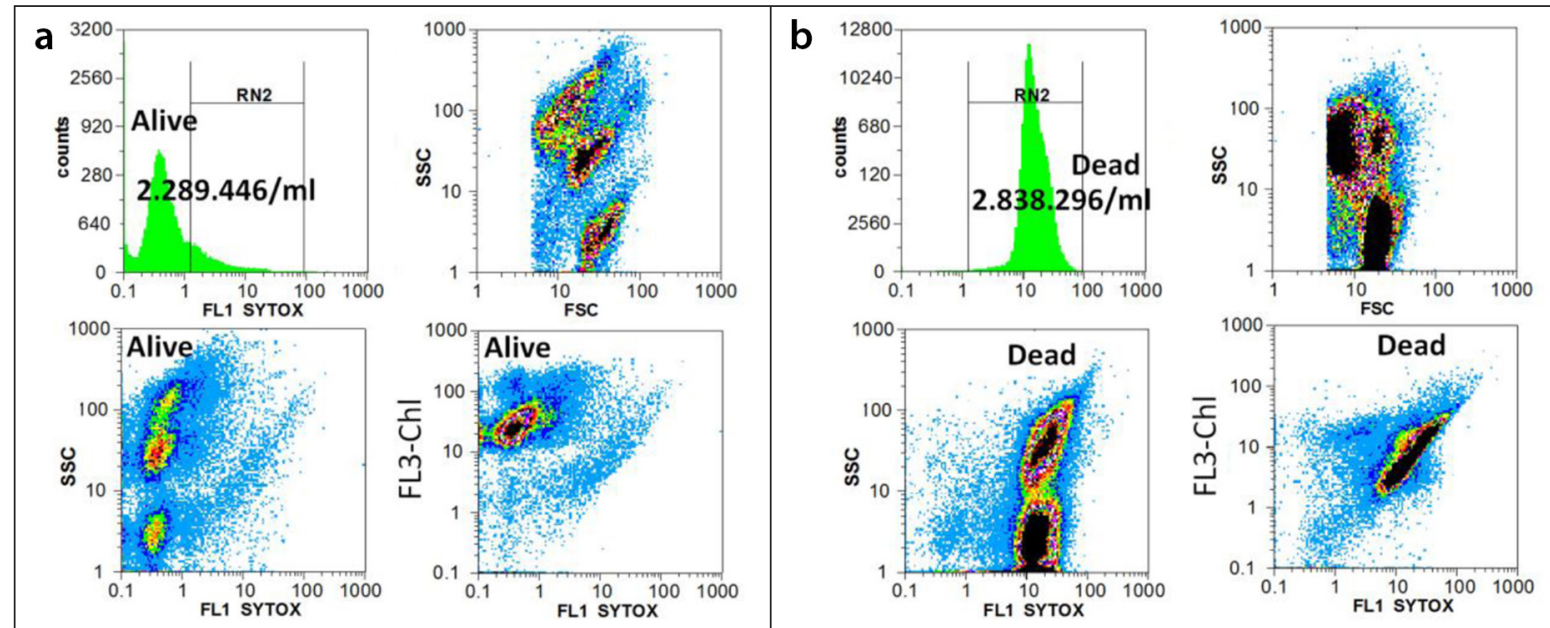

Figure 4. Flow cytometry results following chlorine treatment of $M$. aeruginosa at concentrations of (a) $0 \mathrm{mg} \cdot \mathrm{L}^{-1}$, and (b) $5 \mathrm{mg} \cdot \mathrm{L}^{-1}$, after $72 \mathrm{~h}$ of treatment. FL1-SYTOX histogram indicates the frequency distribution of dead cells as detected by high fluorescence at $520 \mathrm{~nm}$. Bivariate plots of FL1-SYTOX and other parameters such as light scatter (SSC and FSC) and red fluorescence from Chl (FL3-Chl) were also analysed (data is not shown).
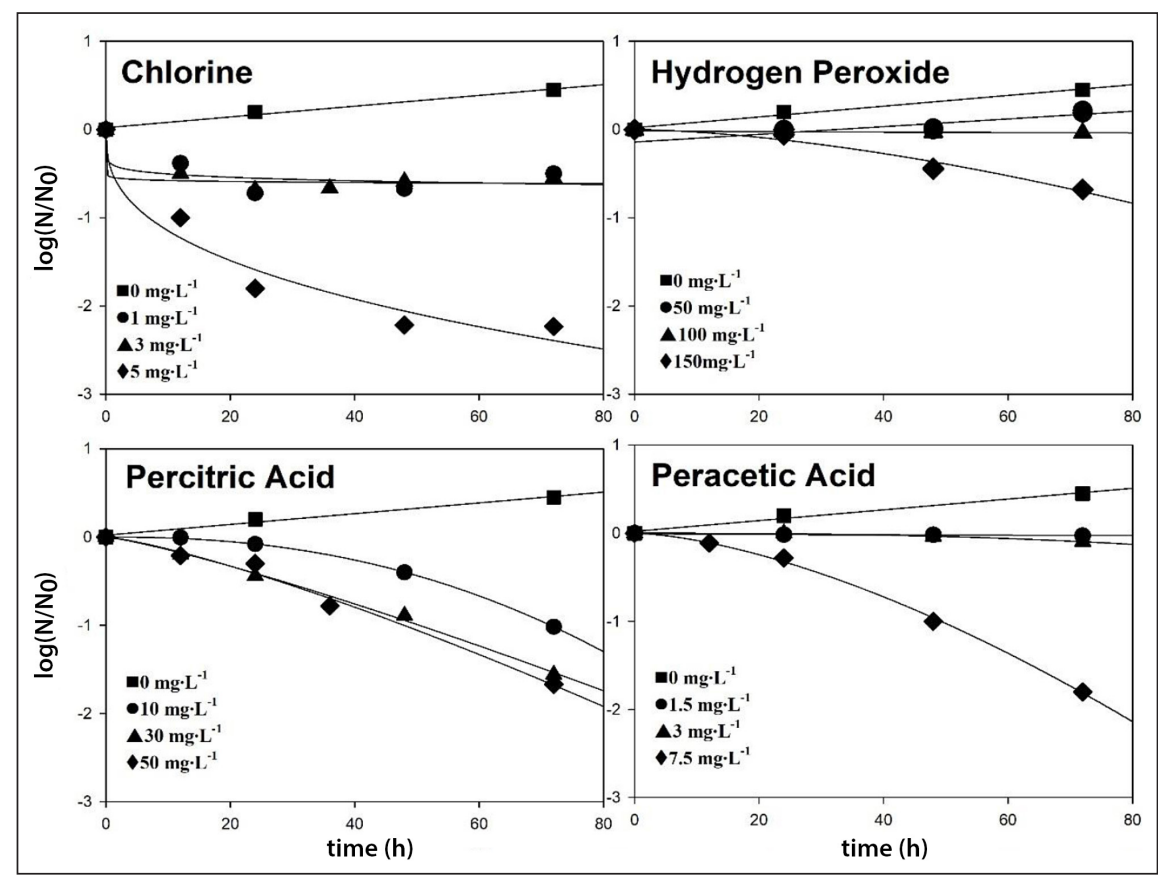

Figure 5. Survival curve of $M$. aeruginosa cells under different treatments; experimental (points) and fitted values derived from the Weibull model (lines)

Considering that $M$. aeruginosa is a non-axenic strain, the effect of oxidants on heterotrophic bacteria that coexist in the culture was also evaluated. For this purpose, the plate counts described in the materials and methods section were performed. In the control sample, the count of heterotrophic bacteria ranged from $7.0 \times 10^{5}-$ $5.2 \times 10^{5} \mathrm{CFU} \cdot \mathrm{mL}^{-1}$ at the beginning and the end of the experiment $(72 \mathrm{~h})$, respectively. A decrease in the counts of heterotrophic bacteria ( 0.85 to $1.02 \log 10)$ was observed in the treated samples with 1,3 and $5 \mathrm{mg} \cdot \mathrm{L}^{-1}$ of chlorine. With HP and PCA a lower decrease in the counts of heterotrophic bacteria was observed (0.10-0.56 $\log 10)$. With $1.5-7.5 \mathrm{mg} \cdot \mathrm{L}^{-1}$ of PAA treatment, a decrease in count ranging from $0.15-0.931 \log 10$ was observed, with a higher microbial inhibitory effect as the oxidant concentration increased.

\section{Modelling of M. aeruginosa decay}

Using the flow cytometer, it was possible to evaluate the number of $M$. aeruginosa viable cells and thereafter generate the corresponding cell survival curves of the control cells and those obtained after treatment with chlorine, HP, PCA and PAA by plotting the $\log$ of survivors (expressed as $\log \left(\mathrm{N} / \mathrm{N}_{0}\right)$ ) against treatment time (Figs 5a, b, c and d, respectively). There were significant differences in the survival curves of M. aeruginosa, depending on the oxidant treatment. The decay of M. aeruginosa after oxidation by chlorine, HP, PCA and PAA exhibited both upward and downward concavity. Control experiments showed no cyanocidal effect on viable cells over $72 \mathrm{~h}$ exposures (Fig. 5). Treatment with 1 and $3 \mathrm{mg} \cdot \mathrm{L}^{-1}$ of chlorine resulted in approximately $0.5-\log$ reduction $(68 \%)$ in $M$. aeruginosa viability, whereas a 2.5- $\log$ reduction was observed with $5 \mathrm{mg} \cdot \mathrm{L}^{-1}$ of chlorine (99\%) at the end of the experiment. Similar reductions were obtained with $50 \mathrm{mg} \cdot \mathrm{L}^{-1}$ of PCA and $7.5 \mathrm{mg} \cdot \mathrm{L}^{-1}$ of PAA (99\%). A reduction of not more than $0.8-\log (84 \%)$ was observed with the highest concentrations of HP (150 mg. L $\left.{ }^{-1}\right)$ (Fig. 5).

The effective concentration of the oxidant required to reduce the initial number of viable cells to half its value at the end of the experiment $(72 \mathrm{~h}$ ) was calculated (Table 2). For chlorine and HP treatment $\left(\mathrm{EC}_{50}\right)_{\mathrm{v}}$ was $0.90 \mathrm{mg} \cdot \mathrm{L}^{-1}$ and $115 \mathrm{mg} \cdot \mathrm{L}^{-1}$, respectively. Similar values of $\left(\mathrm{EC}_{50}\right)_{\mathrm{v}}\left(7.80-7.04 \mathrm{mg} \cdot \mathrm{L}^{-1}\right)$ for viable cells were achieved with PCA and PAA, respectively (Table 2). Figure 5 also shows the fit of the Weibull model (Eq. 5). The control samples and those obtained with $50 \mathrm{mg} \cdot \mathrm{L}^{-1}$ of $\mathrm{HP}$ had a non-cyanocidal effect and showed a better fit with a linear model. The parameters were slope $-0.14( \pm 0.04)$ (positive values), and intercept -0.0044 $( \pm 0.0002)$ with $R^{2}$ of 0.89 for $50 \mathrm{mg} \cdot \mathrm{L}^{-1}$ of $\mathrm{HP}$. 
Table 2. Estimates of Weibull distribution parameters $n, B$ for $M$. aeruginosa survival under different treatment with oxidants. Percentage of degradation of MC at $72 \mathrm{~h}(\% \mathrm{DM})$ and concentration of oxidants at which $50 \%$ of the viability of $M$. aeruginosa was affected (EC $\left.{ }_{50}\right)_{\mathrm{v}}$.

\begin{tabular}{|c|c|c|c|c|c|c|c|c|}
\hline Treatment & $\begin{array}{c}\text { Concentration } \\
\left(\mathrm{mg} \cdot \mathrm{L}^{-1}\right)\end{array}$ & $n$ & $B$ & $R^{2}$ & RMSE & $\begin{array}{l}T_{r} \\
\text { (h) }\end{array}$ & $\begin{array}{c}\% \\
\text { DM }\end{array}$ & $\begin{array}{l}\left(E C_{50}\right)_{v} \\
\left(\mathrm{mg} \cdot \mathrm{L}^{-1}\right)\end{array}$ \\
\hline \multirow[t]{3}{*}{ Chlorine } & 1 & $0.15( \pm 0.01)^{\mathrm{a}}$ & $0.36\left( \pm 4 \times 10^{-2}\right)^{a}$ & 0.981 & 0.044 & $>1000$ & 61 & 0.90 \\
\hline & 3 & $0.12( \pm 0.08)^{\mathrm{a}}$ & $0.37\left( \pm 1 \times 10^{-2}\right)^{a}$ & 0.983 & 0.066 & $>1000$ & 72 & \\
\hline & 5 & $0.37( \pm 0.10)^{\mathrm{a}}$ & $0.48\left( \pm 2 \times 10^{-2}\right)^{\mathrm{a}}$ & 0.989 & 0.077 & $141( \pm 7)$ & 81 & \\
\hline \multirow[t]{3}{*}{ HP } & 50 & ---- & ---- & ---- & ---- & -- & 8 & 115 \\
\hline & 100 & $1.09( \pm 0.21)^{\mathrm{b}}$ & $6.10^{-4}\left( \pm 2 \times 10^{-4}\right)^{b}$ & 0.982 & 0.005 & $>1000$ & 12 & \\
\hline & 150 & $1.51( \pm 0.22)^{\mathrm{b}}$ & $1.10^{-3}\left( \pm 9 \times 10^{-4 b}\right.$ & 0.987 & 0.079 & $200( \pm 9)$ & 24 & \\
\hline \multirow[t]{3}{*}{ PCA } & 10 & $2.30( \pm 0.18)^{b}$ & $5.10^{-5}\left( \pm 4 \times 10^{-6}\right)^{b}$ & 0.989 & 0.039 & $119( \pm 8)$ & 39 & 7.80 \\
\hline & 30 & $1.62( \pm 0.19)^{b}$ & $1.10^{-3}\left( \pm 2 \times 10^{-4}\right)^{b}$ & 0.989 & 0.051 & $125( \pm 8)$ & 66 & \\
\hline & 50 & $1.56( \pm 0.12)^{\mathrm{b}}$ & $2.10^{-3}\left( \pm 1 \times 10^{-4}\right)^{b}$ & 0.994 & 0.068 & $118( \pm 9)$ & 79 & \\
\hline \multirow[t]{3}{*}{ PAA } & 1.5 & $1.08( \pm 0.17)^{\mathrm{b}}$ & $2.10^{-4}\left( \pm 1 \times 10^{-4}\right)^{b}$ & 0.996 & 0.002 & $>1000$ & 18 & 7.04 \\
\hline & 3.0 & $1.40( \pm 0.15)^{\mathrm{b}}$ & $2.10^{-4}\left( \pm 7 \times 10^{-5}\right)^{b}$ & 0.988 & 0.002 & $961( \pm 19)$ & 45 & \\
\hline & 7.5 & $1.57( \pm 0.03)^{\mathrm{b}}$ & $2.10^{-3}\left( \pm 6 \times 10^{-4}\right)^{b}$ & 0.999 & 0.028 & $105( \pm 10)$ & 47 & \\
\hline
\end{tabular}

$n$ and $B$ : constants of Weibull model, $\mathrm{R}^{2}$ : determination coefficient, RMSE: standard error of estimate (Eq. 7), $\mathrm{T}_{\mathrm{r}}$ : time to decay population 3 log units: the required time to achieve $99.9 \%$ decay in viable cell number with respect to the initial number.

Table 3. Parameters yo, $a, b$ and c obtained by fitting the cubic polynomial model with experimental data for $M$. aeruginosa

\begin{tabular}{|c|c|c|c|c|c|}
\hline Treatment & yo & $A$ & $b$ & $c$ & $R^{2}$ \\
\hline Chlorine & $0.17( \pm 0.16)$ & $-3.69( \pm 3,35)$ & $26.40( \pm 22.6)$ & $-51.7( \pm 50.2)$ & 0.75 \\
\hline HP & $0.11( \pm 0.04)$ & $-2.30( \pm 0.87)$ & $15.47( \pm 5.62)$ & $-20.1( \pm 11.7)$ & 0.86 \\
\hline PCA & $0.26( \pm 0.19)$ & $-4.45( \pm 3.62)$ & $24.73( \pm 2.38)$ & $-33.3( \pm 5.2)$ & 0.71 \\
\hline PAA & $1.57( \pm 0.94)$ & $-29.89( \pm 18.03)$ & $187.7( \pm 112.7)$ & $-375.7( \pm 31.8)$ & 0.56 \\
\hline
\end{tabular}

Table 2 shows the $B$ and $n$ parameters of the Weibull model for each treatment. The predicted values were consistent with experimental data having a determination coefficient $\left(R^{2}\right)$ ranging between 0.981 and 0.999 and RMSE less than 0.079 (Table 2). This shows that the Weibull model can explain between 98.1 and $99.9 \%$ of the variation in the experimental data.

The parameter $B$ indicates how quickly $M$. aeruginos $a$ is inactivated under different oxidant conditions (Van Boekel, 2002); it can be observed that $B$ values increased with an increase in the concentrations of the oxidants. As expected, the $n$ - or shape - parameter was less than 1 for chlorine inactivation curves, in accordance with the upward concavity. For other oxidants (HP, PCA and PAA), the $n$ values were greater than 1 and a downward concavity was observed.

It is possible to predict the time of a given decrease in the microbial population according to Eq. 6 , using the $B$ and $n$ parameters. In the present study, the time of a 3-log reduction $\left(T_{r}\right)$ was selected as the time required for $99.9 \%$ decay in the number of viable cells with respect to the initial number. The $T_{r}$ value is analogous to the classic D-value when a $3-\log$ reduction $\left(\log \left(N / N_{0}\right)=3\right.$ or $99.9 \%$ of the reduction in viable cell number) was calculated (Manas and Pagan, 2005) and the values are shown in Table 2. For instance, the $T_{r}$ values varied between 118 and $125 \mathrm{~h}$ for treatment with 10 and $50 \mathrm{mg} \cdot \mathrm{L}^{-1}$ of PCA, whereas a similar reduction required 105 $\mathrm{h}$ with $7.5 \mathrm{mg} \cdot \mathrm{L}^{-1}$ of PAA and $141 \mathrm{~h}$ with $5 \mathrm{mg} \cdot \mathrm{L}^{-1}$ of chlorine. HP (150 $\mathrm{mg} \cdot \mathrm{L}^{-1}$ ) was the oxidizing agent that required the longest amount of time to achieve a $99.9 \%$ cell reduction (200 h) (Table 2).

Since $M$. aeruginosa is a non-axenic culture, the experimental system assayed can be considered to be heterogeneous (heterotrophic bacteria coexist, also presents a layer of polysaccharide mucilage) and these results can therefore be taken as a good correlation. The biological meaning of the $n$ and $B$ parameters of the Weibull model has been described by Peleg (2006). Upward concavity $(n<1)$ indicates that sensitive cells in the population die rapidly, leaving only the most resistant cells as survivors. Downward concavity of the survival curve (with $n>1$ ) indicates that continued exposure and the resulting cumulative damage causes loss of resistance to the treatment and the cells die at progressively shorter times. Although the Weibull model is empirical, it can nevertheless be used to interpret the physiological effects of oxidizing agents on M. aeruginosa.

\section{Relationship between $\mathrm{Chl}-a$ and viable cells of M. aeruginosa}

Several simple polynomial equations were tested to relate $\ln ($ Chl- $a$ ) vs $\ln$ (viable cells). A polynomial of third degree was found to successfully fit the data:

$$
\ln (N)=y o(\ln (\mathrm{Chl}-a))^{3}+a(\ln (\mathrm{Chl}-a))^{2}+b(\ln (\mathrm{Chl}-a))+c
$$

where $N$ is $M$. aeruginosa number (cells $\left.\mathrm{mL}^{-1}\right), \mathrm{Chl}-a\left(\mu \mathrm{g} \cdot \mathrm{L}^{-1}\right)$ and yo, $a, b$ and $c$ are constants.

In Fig. 6 it is possible to observe the fitting of $\ln (\mathrm{Chl}-a)$ vs $\ln$ (viable cells) values for each oxidant. Table 3 shows the parameters of polynomials and $R^{2}$ values. A good correlation was obtained by applying the proposed model, with $R^{2}$ ranging from $0.56-0.86$. For the prediction of viable cells from experimental Chl- $a$ values, it is possible to employ the polynomial model. Considering that Chl- $a$ determination is easy, simple and inexpensive, the polynomial model allows prediction of the number of viable cells.

\section{Toxin removal}

The initial level of [D-Leu $\left.{ }^{1}\right] \mathrm{MC}-\mathrm{LR}$ in the culture of $M$. aeruginosa ranged between 50 and $200 \mu \mathrm{g} \cdot \mathrm{L}^{-1}$. No degradation of [D-Leu $\left.{ }^{1}\right]$ MC-LR was observed in the control samples. By contrast, $[\mathrm{D}-\mathrm{Leu}]^{1} \mathrm{MC}-\mathrm{LR}$ had increased values ranging between 120 and $350 \mu \mathrm{g} \cdot \mathrm{L}^{-1}$ at the end of the experiment. After $72 \mathrm{~h}$ of exposure to HP, PCA and PCA, considerable [D-Leu $]^{1}$ MC-LR degradation was observed (Table 2). The percentages of degradation of [D-Leu $\left.{ }^{1}\right] \mathrm{MC}-\mathrm{LR}$ relative to the initial values $(\% \mathrm{DM})$ are shown in Table 2. A 1-5 mg. $\mathrm{L}^{-1}$ dose of chlorine was consumed very quickly, causing [D-Leu $\left.{ }^{1}\right]$ MC-LR release from Microcystis cells and significant degradation (61-81\%). A chlorine dose of $>5 \mathrm{mg} \cdot \mathrm{L}^{-1}$ can also augment disinfection by-product (DBP) concentrations (Fan et al., 2013) and increase health risks. A similar extent of degradation (66-79\%) was achieved with $30-50 \mathrm{mg} \cdot \mathrm{L}^{-1}$ of PCA. By the end of the treatment, $45-47 \%$ degradation was obtained with $3.0-7.5 \mathrm{mg} \cdot \mathrm{L}^{-1}$ of PAA, and $24 \%$ with $150 \mathrm{mg} \cdot \mathrm{L}^{-1}$ of $\mathrm{HP}$. 


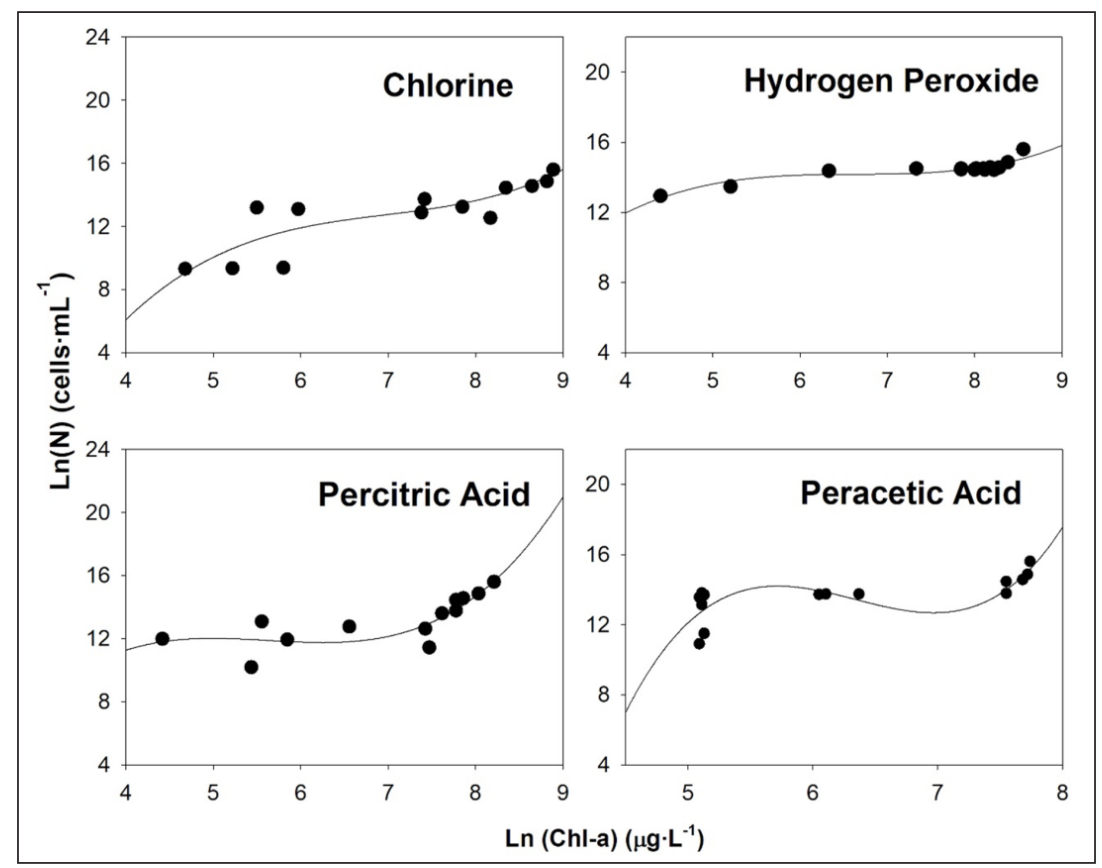

Figure 6. In (Chl-a) vs $\ln (N)$ plot by fitting the cubic polynomial model with experimental data for M. aeruginosa

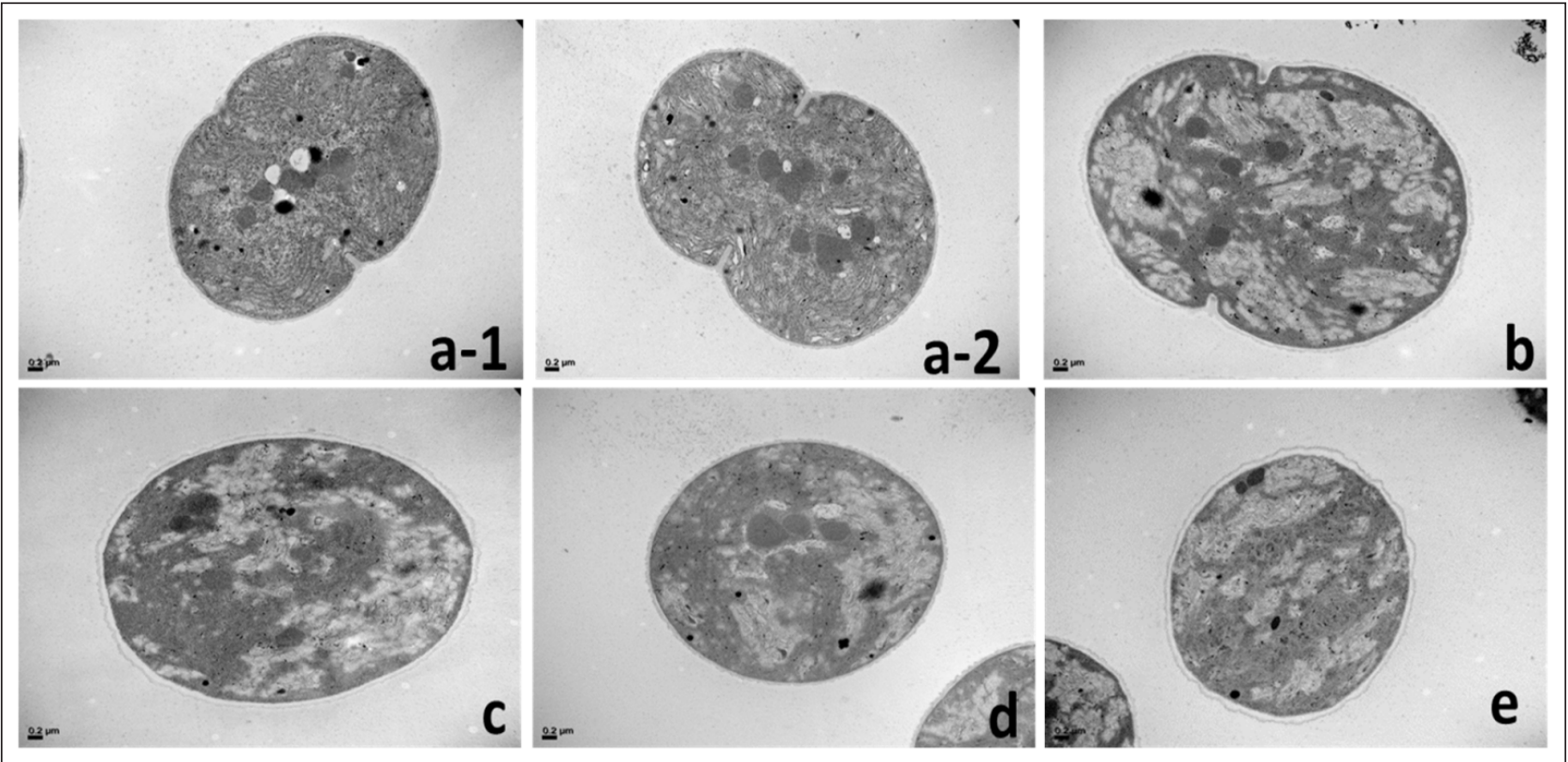

Figure 7. Ultrastructure of $M$. aeruginos $a$ after $72 \mathrm{~h}$ of contact by different treatments: (a-1) and (a-2) control cells, (b) $5 \mathrm{mg} \cdot \mathrm{L}^{-1} \mathrm{chlorine}$, (c) $50 \mathrm{mg} \cdot \mathrm{L}^{-1}$ PCA, (d) $150 \mathrm{mg} \cdot \mathrm{L}^{-1} \mathrm{HP}$ and (e) $7.5 \mathrm{mg} \cdot \mathrm{L}^{-1} \mathrm{PAA}$

\section{Transmission electron microscopy (TEM)}

The control cells showed a dense and well-defined dense cytoplasm, without vacuolation zones and a conserved thylakoid net. The cytomembrane maintains its shape and structure (Figs 7 a-1 and a-2). In the treated cells, membrane deformation, less dense stroma, partial loss of the thylakoid net and extensive areas of cellular vacuolization can be observed. These damages to the cells are more evident in Fig. 7b, corresponding to cells treated with $5 \mathrm{mg} \cdot \mathrm{L}^{-1}$ of chlorine. Deformation, disintegration of thylakoids and cytoplasmic vacuolation were also observed after exposure with $50 \mathrm{mg} \cdot \mathrm{L}^{-1} \mathrm{PCA}, 150 \mathrm{mg} \cdot \mathrm{L}^{-1} \mathrm{HP}$ and $7.5 \mathrm{mg} \cdot \mathrm{L}^{-1} \mathrm{PAA}$ (Fig. 7c, d and e).

\section{DISCUSSION}

One method used to assess the toxic action of oxidants on Chl- $a$ degradation and cell viability is by calculating $\mathrm{EC}_{50}$. Depending on the endpoint (Chl- $a$ or viability), chlorine proved to be the most effective oxidant since it produced the lowest $\mathrm{EC}_{50}$ values, varying between 0.70 and $0.90 \mathrm{mg} \cdot \mathrm{L}^{-1}$. For PAA, the values ranged from $4.02-$ $7.04 \mathrm{mg} \cdot \mathrm{L}^{-1}$ and for PCA from $17.76-7.80 \mathrm{mg} \cdot \mathrm{L}^{-1}$ (Tables 1 and 2). $\mathrm{HP}$ produced the highest $\mathrm{EC}_{50}$ values, ranging from 102-115 $\mathrm{mg} \cdot \mathrm{L}^{-1}$ (Tables 1 and 2). $\mathrm{EC}_{50}$ values ranging from 0.3 to $0.5 \mathrm{mg} \cdot \mathrm{L}^{-1}$ were found in the literature for another strain of $M$. aeruginosa treated with HP (Wang et al., 2012). For field-collected colonial $M$. aeruginosa, a relatively high $\mathrm{EC}_{50}$ of about $30 \mathrm{mg} \cdot \mathrm{L}^{-1}$ for $\mathrm{HP}$ has been previously reported (Wang et al., 2012). The high value of $\mathrm{EC}_{50}$ reported in the present work (102-115 $\left.\mathrm{mg} \cdot \mathrm{L}^{-1}\right)$ could be due to the use of extremely high cyanobacteria concentrations tested $\left(10^{6} \mathrm{cell} \cdot \mathrm{mL}^{-1}\right)$. In this study, the degradation of Chl- $a$ by a first-order kinetic model was successfully applied to the experimental data. The $k_{0}$ values were higher with an increase in oxidant doses, indicating a faster Chl- $a$ decay. Chlorine was the best oxidant treatment, followed by PAA and PCA, since it required a lower concentration of oxidant to produce a rapid and effective degradation of Chl- $a$. HP had the weakest effect on Chl- $a$ degradation. 
In addition, the Chl- $a$ degradation model can be successfully applied to predict the Chl- $a$ value for any concentration of oxidant in the range studied. For instance, for $80 \mathrm{mg} \cdot \mathrm{L}^{-1}$ of $\mathrm{HP}$, it is possible to predict $k_{0}$ values by Eq. 4 and the corresponding parameters $a=1.4 .10^{-2}\left( \pm 8.1 \times 10^{-3}\right), b=-3.1 \times 10^{-4}\left( \pm 8.6 \times 10^{-5}\right)$ (Fig. 3). The calculated $k_{0}$ is $1.08 \times 10^{-2} \mathrm{~h}^{-1}$, and then from Eq. 2, with Chl- $a$ initial of $2514 \mu \mathrm{g} \cdot \mathrm{L}^{-1}$ at $72 \mathrm{~h}$ of treatment, the predicted value of Chl- $a$ is $1155 \mu \mathrm{g} \cdot \mathrm{L}^{-1}$.

Chl- $a$ decay was satisfactorily adjusted by means of linear regression kinetics but the kinetics of cell reduction was not linear. This is frequently the case when there is a mixture of oxidantresistant and sensitive sub-populations of bacteria. This does not occur with the degradation of Chl- $a$, the latter being a chemical compound whose degradation is assumed to be a simple chemical event, unaffected by such factors as the high density of cells or the infrequent re-suspension of cells through stirring (Shaman and Lorenxen, 1975).

According to the Weibull model, concave upward $(n<1)$ survival curves of $M$. aeruginosa treated with different concentrations of chlorine can be interpreted as evidence that weak or sensitive members of the populations die at a relatively fast rate, leaving behind survivors with initial higher resistance and/or which have adapted to the oxidant stress (Peleg and Cole, 1998).

HP, PCA and PAA recorded ' $n$ ' values that were $>1$, which indicate that the remaining cells became increasingly susceptible to oxidants, and the cumulative damage made it increasingly difficult for them to survive. All oxidants tested inactivated M. aeruginosa by direct action through the formation of active oxidizing agents, such as hypochlorous acid, hypochlorite ion and other chlorinecontaining oxidants and indirect oxidation by ROS.

Chlorination of heavily algae-laden water, especially in the presence of $M$. aeruginosa, may be very risky since chlorination can potentially cause severe cyanobacteria cell cytoclasis and MC-LR release. However, in the present study, $5 \mathrm{mg} \cdot \mathrm{L}^{-1}$ of chlorine produced a $77.0 \%$ degradation of [D-Leu $\left.{ }^{1}\right]$ MC-LR after $72 \mathrm{~h}$; it took $141 \mathrm{~h}$ to reduce viable cells by $99.9 \%$. Although not reported in the literature, it is likely that the effect of PCA and PAA on cyanobacteria is similar to that of $\mathrm{HP}$, since they both produce HP in their reactions. Among peroxide treatments (HP, PCA and PAA), PCA (30-50 mg. $\left.\mathrm{L}^{-1}\right)$ produced the highest level of MC degradation (66-79\%) (Table 2). PAA (3.0-7.5 mg. $\left.\mathrm{L}^{-1}\right)$ and HP (100-150 mg. $\mathrm{L}^{-1}$ ) showed lower MC degradation values: $45-47 \%$ and $12-24 \%$, respectively. These data therefore point to PCA as the peroxide of choice among those assayed.

It is important to note that PCA and PAA achieved the removal of more cells and a greater degradation of [D-Leu $\left.{ }^{1}\right] \mathrm{MC}-\mathrm{LR}$ than HP alone, probably because they contain HP (30\% mass/volume) as part of the makeup of their compounds which could increase their toxicity for M. aeruginosa and degrade the released toxin.

The different peroxide treatments (HP, PCA and PCA) may have catalysed the production of hydroxyl and hydroperoxyl radicals that induced the oxidative cleavage of microcystins. MC-LR could be degraded into peptide residues by either modifying the Adda-moiety or breaking the amino-acid ring structure of the microcystins (Antoniou et al., 2008; Liu et al., 2003).

Hydrogen peroxide (HP) is selective for cyanobacteria (vs. eukaryotic algae and higher plants) and poses no serious longterm threats to the system because of its rapid decomposition without producing persistent toxic chemicals or by-products that cause aesthetic odour or colour issues (Matthijs et al., 2012). It has been reported that HP has potential for removing Microcystis spp. and MCs in different environments (Cornish et al., 2000; Drábková et al., 2007a; Barrington and Ghadouani, 2008; Wang et al., 2012).
It is possible that the oxidants initially reacted with the cellbound mucilage before reaching the outer membrane. The $M$. aeruginosa CAAT2005-3 used in this work is a mucilageproducing cyanobacteria, the cells being embedded within a matrix of mucilage comprised of polysaccharides. The ratio of mucilage volume to cell volume has been reported to be 0.50 for M. aeruginosa CAAT2005-3 (Rosso et al., 2014). It is likely that the mucilage provides an oxidative demand that consumes $\mathrm{OH}$ radicals and protects the cell membrane from oxidative attack until sufficient damage accumulates on the cell surface to breach cell integrity.

It is not always possible to compare the results obtained in laboratory experiments with those obtained in the field since factors such as water quality and hydraulic conditions vary greatly and affect oxidation efficiency. The formation of $\mathrm{OH}$ radicals, for instance, and the decay of oxidants are influenced by $\mathrm{pH}$, dissolved organic matter, inorganic radical scavengers, other possible contaminants and the presence of bacteria. Humic acid and nitrates, two common water solutes, can inhibit the processes of cellular inactivation and toxin degradation, due to the ROS scavenging and 'inner filter' effect. Furthermore, the formation of cyanobacterial colonies of different sizes under natural conditions and colonies with mucilage or sheaths may enhance cell resistance to oxidative stress (Huo et al., 2015). Variations in morphology, physical and biochemical characteristics between individual and colonial Microcystis cells were found (Fan et al., 2016). Such differences need to be considered when determining dose levels under real situations. Consequently, it is important to modify the parameters of oxidation (concentration and time) and include a full-scale trial based on the results of this study before application in natural waters.

\section{CONCLUSION}

The Weibull model showed a good fit to the data for the inactivation kinetics of $M$. aeruginosa in culture media and it was possible to predict the required exposure time to oxidants to achieve $99.9 \%$ reduction in viable cells. The shortest time of exposure was achieved with PCA (10-50 mg. $\left.\mathrm{L}^{-1}\right)$ and required $118-125 \mathrm{~h}$.

$\mathrm{HP}$ was the oxidant that required the longest time to achieve a $99.9 \%$ reduction $(200 \mathrm{~h})$. A concentration of $5 \mathrm{mg} \cdot \mathrm{L}^{-1}$ chlorine significantly reduced $M$. aeruginos $a$ viability and was accompanied by a decline in the total microcystin concentrations (81\%). The application of $7.5 \mathrm{mg} \cdot \mathrm{L}^{-1}$ of PAA presented a $47 \%$ degradation of [D-Leu ${ }^{1}$ MC-LR, and $150 \mathrm{mg} \cdot \mathrm{L}^{-1}$ of HP a $24 \%$ degradation. With $30-50 \mathrm{mg} \cdot \mathrm{L}^{-1}$ of PCA, a $66-79 \%$ degradation of [D-Leu ${ }^{1}$ MC-LR was obtained. These data therefore point to PCA as the peroxide of choice among those assayed. The present study also revealed that added chlorine and peroxide (HP, PCA and PAA) were degraded within $72 \mathrm{~h}$ and thus no residual values in the culture media were detected.

PCA and PAA could be considered as a possible strategy for bloom control due to the fact that they act as alternatives that offer low cost and less environmental impact. These are new oxidants that have been recently been applied at scale in a wastewater treatment plant. In this study, the oxidants have been shown to be effective in decreasing $M$. aeruginosa cells, degrading Chl- $a$ and [D-Leu ${ }^{1}$ ] MC-LR in a culture medium. A full-scale trial based on the results of this study is necessary to complete the evaluation for treating water sources with cyanobacterial blooms.

\section{ACKNOWLEDGEMENTS}

This study was financially supported by University National of La Plata (UNLP X526), National Agency of Scientific and Technical Research (PICT0861-2013) and CONICET (PIP0959). 


\section{REFERENCES}

AGUILERA A and ECHENIQUE RO (2017) Cyanobacteria nocivas de ambientes acuáticos continentales: taxonomía y ecología. In: Giannuzzi L (ed.) Cianobacterias como determinantes ambientales de salud. Ministerio de Salud. 27-48. ISBN 978-950-38-0255-7.

ANTONIOU MG, SHOEMAKER JA, DE LA CRUZ AA and DIONYSIOU DD (2008) Unveiling new degradation intermediates/ pathways from the photocatalytic degradation of microcystinLR. Environ. Sci. Technol. 42 8877-8883. https://doi.org/10.1021/ es801637z.

APHA (2005) Standard Methods for Examination of Water and Wastewater (21 $1^{\text {st1 }}$ edn) (2005) American Public Health Association / American Water Works Association / Water Environment Federation, Washington, DC.

BARCO M, LAWTON LA, RIVERA J and CAIXACH J (2005) Optimization of intracellular microcystin extraction for their subsequent analysis by high-performance liquid chromatography. J. Chromatog. A. 1074 (1) 23-30. https://doi.org/10.1016/j.chroma. 2005.03.087

BARRINGTON DJ and GHADOUANI A (2008) Application of hydrogen peroxide for the removal of toxic cyanobacteria and other phytoplankton from wastewater. Environ. Sci. Technol. 42 (23) 8916-8921. https://doi.org/10.1021/es801717y

BARROIN G and FEUILLADE M (1986) Hydrogen peroxide as a potential algicide for Oscillatoria rubescens D.C. Water Res. 20619 623. https://doi.org/10.1016/0043-1354(86)90026-6

BAUZÁ L, AGUILERA A, ECHENIQUE R, ANDRINOLO D and GIANNUZZI L (2014) Application of hydrogen peroxide to the control of eutrophic lake systems in laboratory assays. Toxins. 6 2657-2675. https://doi.org/10.3390/toxins6092657

BOOTH RA and LESTER JN (1995) The potential formation of halogenated by-products during peracetic acid treatment of final sewage effluent. Water Res. 29 1793-1801. https://doi.org/ 10.1016/0043-1354(94)00263-7

CHUN H, KIM J, CHUNG K, WON M and SONG KB (2009) Inactivation kinetics of Listeria monocytogenes, Salmonella enterica serovar Typhimurium, and Campylobacter jejuni in ready-to-eat sliced ham using UV-C irradiation. Meat Sci. 83 599-603. https:// doi.org/10.1016/j.meatsci.2009.07.007

CORNISH BJ, LAWTON LA and ROBERTSON PKJ (2000) Hydrogen peroxide enhanced photocatalytic oxidation of microcystin-LR using titanium dioxide. Appl. Catal., B-Environ. 25 59-67. https:// doi.org/10.1016/S0926-3373(99)00121-6

CREBELLI R, CONTI L, MONARCA S, FERRETTI D, ZERBINI I, ZANI C, VESCHETTI E, CUTILLI D and OTTAVINI M (2005) Genotoxicity of the disinfection by-products resulting from peracetic acid or hypochlorite disinfected sewage wastewater. Water Res. 39 1105-1113. https://doi.org/10.1016/j.watres.2004.12.029

DRÁBKOVÁ M, ADMIRAAL W and MARŠÁLEK MB (2007a) Combined exposure to hydrogen peroxide and light: Selective effects on cyanobacteria, green algae, and diatoms. Environ. Sci. Technol. 41 309-314. https://doi.org/10.1021/es060746i

FALSANISI D, GEHR R, SANTORO D, DELL'ERBA A NOTARNICOLA $M$ and LIBERTI L (2006) Kinetics of PAA demand and its implications on disinfection of wastewaters. Water Qual. Res. 41 398-409. https://doi.org/10.2166/wqrj.2006.043

FAN J, HO L, HOBSON P and BROOKES J (2013) Evaluating the effectiveness of copper sulphate, chlorine, potassium permanganate, hydrogen peroxide and ozone on cyanobacterial cell integrity. Water Res. 47 (14) 5153-5164. https://doi.org/10.1016/j.watres.2013.05.057

FAN J, RAO L, CHIU Y and LIN T (2016) Impact of chlorine on the cell integrity and toxin release and degradation of colonial Microcystis. Water Res. 102 394-404.https://doi.org/10.1016/j.watres.2016.06.053

GIANNUZZI L, KROCKC B, CRETTAZ MINAGLIA MC, ROSSO L, HOUGHTON C, SEDAN D, MALANGA G, ESPINOSA M ANDRINOLO D and HERNANDO M (2016) Growth, toxin production, active oxygen species and catalase activity of Microcystis aeruginosa (Cyanophyceae) exposed to temperature stress. Comp. Biochem. Physiol. B. 189 22-30. https://doi.org/10.1016/j.cbpc.2016. 07.001

GONZÁLEZ M, SKANDAMIS PN and HÄNNINEN M (2009) A modified Weibull model for describing the survival of Campylobacter jejuni in minced chicken meat. Int. J. Food Microbiol. 136 52-58. https://doi.org/10.1016/j.ijfoodmicro.2009.09.022
HARKEM, STEFFEN M, GOBLER C, OTTEN T, WILHELM S, WOODF $S$ and PAERL H (2016) A review of the global ecology, genomics, and biogeography of the toxic cyanobacterium, Microcystis spp. Harmful Algae. 54 4-20. https://doi.org/10.1016/j.hal.2015.12.007

HUO X, CHANG D, TSENG J, BURCH M and LIN T (2015) Exposure of Microcystis aeruginosa to hydrogen peroxide under light: Kinetic modeling of cell rupture and simultaneous Microcystin degradation. Environ. Sci. Technol. 49 5502-5510. https://doi.org/10.1021/acs.est. 5b00170

IZYDORCZYK I, CARPENTIER K, MRÓWCZYŃSKI J, WAGENVOORT A, JURCZAK T and TARCZYŃSKA M (2009) Establishment of an alert level framework for cyanobacteria in drinking water resources by using the algae online analyser for monitoring cyanobacterial chlorophyll-a. Water Res. 43 989-996. https://doi.org/10.1016/j.watres.2008.11.048

JÖHNK KD, HUISMAN J, SHARPLES J, SOMMEIJER B, VISSER PM and STROOM JM (2008) Summer heatwaves promote blooms of harmful cyanobacteria. Glob. Change Biol. 14 495-512. https://doi. org/10.1111/j.1365-2486.2007.01510.x

KOSTEN S, HUSZAR VLM, BÉCARES E, COSTA LS, VAN DONK E, HANSSON LA, JEPPESEN E, KRUK C, LACEROT G, MAZZEO N, DE MEESTER L and co-authors (2012) Warmer climates boost cyanobacterial dominance in shallow lakes. Glob. Change Biol. 18 118-126. https://doi.org/10.1111/j.1365-2486.2011.02488.x

LEFEVRE F, AUDIC JM and FERRAND F (1992) Peracetic acid disinfection of secondary effluents discharged off coastal seawater. Water Sci. Technol. 25 155-163. https://doi.org/10.2166/wst.1992.0347

LIU I, LAWTON LA and ROBERTSON PKJ (2003) Mechanistic studies of the photocatalytic oxidation of microcystin-LR: an investigation of byproducts of the decomposition process. Environ. Sci. Technol. 37 3214-3219. https://doi.org/10.1021/es0201855

MANAS P and PAGAN R (2005) Microbial inactivation by new technologies of food preservation. J. Appl. Microbiol. 98 (6) $1387-$ 1399. https://doi.org/10.1111/j.1365-2672.2005.02561.x

MAFART P, COUVERT O, GAILLARD S and LEGUERINEL I (2002) On calculating sterility in thermal preservation methods: application of the Weibull frequency distribution model. Int. J. Food Microbiol. 72 107-113. https://doi.org/10.1016/S0168-1605(01)00624-9

MARKER AFH, CROWTHER CA and GUNN RJM (1980) Methanol and acetone as solvents for estimating chlorophyll a and phaeopigments by spectrophotometry. Arch. Hydrobiol. Beih. Ergebn. Limnol. 14 52-69.

MATTHIJS H, VISSER P, REEZE B, MEEUSE J, SLOT P, WIJN G, TALENS R and HUISMAN J (2012) Selective suppression of harmful cyanobacteria in an entire lake with hydrogen peroxide. Water Res. 46 1460-1472. https://doi.org/10.1016/j.watres.2011.11.016

MATTHIJS H, JANČULA D, VISSER P and MARŠÁLEK B (2016) Existing and emerging cyanocidal compounds: new perspectives for cyanobacterial bloom mitigation. Aquat Ecol. 50 443-460. https:// doi.org/10.1007/s10452-016-9577-0

MONARCA S, RICHARDSON SD, FERETTI D, GROTTOLO M THRUSTON AD, ZANI C, NAVAZIO G, RAGAZZO P, ZERBINI I and ALBERTI A (2002) Mutagenicity and disinfection byproducts in surface drinking water disinfected with peracetic acid. Environ. Toxicol. Chem. 21 309-318. https://doi.org/10.1002/etc.5620210212

PAERL HW and HUISMAN J (2008) Blooms like it hot. Science. 320 57-58. https://doi.org/10.1126/science.1155398

PAERL HW and OTTEN TG (2013) Harmful cyanobacterial blooms: causes, consequences, and controls. Microbial Ecol. 65 995-1010. https://doi.org/10.1007/s00248-012-0159-y

PELEG $M$ and COLE MB (1998) Reinterpretation of microbial survival curves. Crit. Rev. Food Sci. Nutr. 38 353-380. https://doi. org/10.1080/10408699891274246

PELEG M (2006) Advanced Quantitative Microbiology for Foods and Biosystems: Models for Predicting Growth and Inactivation. CRC Series in Contemporary Food Science. CRC Press, Boca Raton, FL. https://doi.org/10.1201/9781420005370

PINKENELL U, KARST U and CAMMAN K (1994) Determination of peroxyacetic acid using high-performance liquid chromatography with external calibration. Anal. Chem. 66 (15) 2599-2602. https:// doi.org/10.1021/ac00087a028

ROSITANO J, NEWCOMBE G, NICHOLSON B and SZTAJNBOK P (2001) Ozonation of NOM and algal toxins in four treated waters. Water Res. 35 (1) 23-32. https://doi.org/10.1016/S00431354(00)00252-9 
ROSSO L, SEDAN D, KOLMAN M, CAIXACH J, FLORES C, OTEIZA JM, SALERNO G, ECHENIQUE R, GIANNUZZI L and ANDRINOLO D (2014) Microcystis aeruginosa strain [D-Leul] Mcyst-LR producer, from Buenos Aires province, Argentina. J. Coast Life Med. 2 (4) 287-296.

SHAMAN R and LORENXEN C (1975) Quantitative degradation of chlorophyll by a marine herbivore. Limnol. Oceanogr. 4(20) 580-586. https://doi.org/10.4319/lo.1975.20.4.0580

SNEDECOR GW and COCHRAN W G (1969) Statistical Methods $\left(6^{\text {th }}\right.$ edn). University Press, Iowa.

STANFORD B, ADAMS C, ROSENFELDT E, AREVALO E and REINERT A (2016) CyanoTOX: tools for managing cyanotoxins in drinking water treatment with chemical oxidants. J. Am. Water Works Assoc. 108 412-446. https://doi.org/10.1155/2019/3231473

TASHYREVA D, ELSTER J and BILLI D (2013) A novel staining protocol for multiparameter assessment of cell heterogeneity in phormidium populations (cyanobacteria) employing fluorescent dyes. PLoS One 8 e55283. https://doi.org/10.1371/journal.pone.0055283

UENO Y, NAGATA S, TSUTSUMI T, HASEGAWA A, WATANABE MF, PARK HD, CHEN GC, CHEN G and YU SZ (1996) Detection of microcystins, a bluegreen algal hepatotoxin, in drinking water sampled in Haimen and Fusui, endemic areas of primary liver cancer in China, by highly sensitive immunoassay. Carcinogenesis. 17 1317-1321. https://doi.org/10.1093/carcin/17.6.1317
USEPA (United States Environmental Protection Agency) (2015) Drinking Water Health Advisory for the Cyanobacterial Microcystin Toxins. USEPA, Washington DC. https://www.epa.gov/cyanohabs/ epa-drinking-water-health-advisories-cyanotoxins

VAN BOEKEL MAJS (2002) On the use of the Weibull model to describe thermal inactivation of microbial vegetative cells. Int. J. Food Microbiol. 74 139-159. https://doi.org/10.1016/S0168-1605(01)00742-5

WANG Z, LI D, QIN H and LIY (2012) An integrated method for removal of harmful cyanobacterial blooms in eutrophic lakes. Environ. Pollut. 160 34-41. https://doi.org/10.1016/j.envpol.2011.09.003

WESTRICK JA, SZLAG DC, SOUTHWELL BJ and SINCLAIR J (2010) A review of cyanobacteria and cyanotoxins removal/inactivation in drinking water treatment. Anal. Bioanal. Chem. 397 1705-1714. https://doi.org/10.1007/s00216-010-3709-5

WHO (World Health Organization) (1999) http://www.who.int/water sanitation_health/resourcesquality/toxcyanchap5.pdf

ZAMYADI A, DORNER S, SAUVE S, ELLIS D, BOLDUC A, BASTIEN $C$ and PREVOST M (2013) Species-dependence of cyanobacteria removal efficiency by different drinking water treatment processes. WaterRes. 472689-2700.https://doi.org/10.1016/j.watres.2013.02.040 ZHAO Y, XIE P and ZHANG X (2009) Oxidative stress response after prolonged exposure of domestic rabbit to a lower dosage of extracted microcystins. Environ. Toxicol. Pharmacol. 27 195-199. https://doi. org/10.1016/j.etap.2008.10.005 